\title{
Control Mechanism and Value of Firm: Empirical Evidence from Indonesia Capital Market
}

\author{
Christian Herdinata*, Eduardus Tandelilin**, Hermeindito*** \\ * Universitas Katolik Widya Mandala Surabaya, Indonesia \\ ** Universitas Gadjah Mada, Indonesia \\ *** Universitas Katolik Widya Mandala Surabaya, Indonesia
}

\begin{tabular}{l} 
A R T I C L E I N F O \\
\hline Keywords: \\
institutional ownership, \\
leverage, \\
asset utilization, \\
corporate performance, \\
tunneling
\end{tabular}

Corresponding author: christian.herdinata@ciputra.ac.id
A B S T R A C T

This research discusses about the roles of institutional ownership and leverage as control mechanism over agency conflict and how it affects corporate performance. Agency conflict is a result of expropriation via tunneling on asset utilization. This study uses panel data with a sample of 136 companies in Indonesia between 2001-2012. Simultaneous model testing using Three Stage Least Square estimation technique is also used in this study. Results suggest that institutional ownership and leverage have a non-linear effect on asset utilization. Institutional ownership can be used as a control mechanism at higher levels of ownership. However, when the ownership surpasses certain level, institutional owners will be able to conduct expropriation through tunneling. Low-level leverage will result in expropriation through tunneling by institutional owners. On the other hand, higher level of leverage makes it possible to use leverage as control mechanism. This study also suggests that there is a substitutional correlation between the implementation of control mechanism and leverage. This research also proves that the effect of control mechanism on asset utilization will improve corporate performance. This research does not specifically investigate the proportions of institutional ownership and leverage as borderline threshold which shows that the two variables can be used as control mechanism. It also implies that the control mechanism over agency conflict which happens as a result of expropriation through tunneling can be done using institutional ownership and leverage. Institutional ownership and leverage must, in this case, be conducted properly towards asset utilization so that it can improve corporate performance. This research provides evidence and solutions for agency conflicts that happen as a result of expropriation through tunneling. This study also contributes to the agency theory testing model by using simultaneous equation and considering non-linear testing method.

(C) 2013 IRJBS, All rights reserved. 


\section{INTRODUCTION}

Majority shareholders can conduct expropriation using corporate policy. However, this may lead to an agency conflict with minority shareholders. Shleifer and Vishny (1986) stated that majority shareholders can use their authority to obtain personal benefits by various means; among them, tunneling. Johnson et al., (2000) defined tunneling as an outgoing resources transfer from corporates for the benefit of controlling shareholders. Related party transactions, as indicated by tunneling, include: cash payment, asset purchases, asset sales, and asset exhcanges (Cheung, Rau, and Stouraitis, 2006; Cheung, Qi, and Rau, 2009). Based on this issue, it is important to prove if tunneling occurs in Indonesian companies. It is also necessary to know how to use control mechanism to reduce expropriation through tunneling in order to decrease agency conflict. Therefore, the primary focus of this study is to improve corporate performance via control mechanism on agency conflict that happens as a result of tunneling-indicated asset utilization.

Several empirical research studies related to control mechanism over agency conflict such as one taken by Jensen and Meckling (1976) show that leverage can reduce agency conflict between managers and shareholders. Furthermore, Jensen (1986) proved that leverage mechanism can reduce agency conflicts caused by overinvestment. Additionally, Kim and Sorensen (1986) and Friend and Lang (1988) found that the decision to increase leverage was consistest with the reduction of agency conflict. This statement is supported by Jensen, Solberg and Zorn (1992) who tested three financial decisions namely leverage, dividens, and insider ownership using a simultaneous equation model. They discovered that leverage and dividens were simultaneously used to reduce agency cost. On the other hand, Bathala, Moon and Rao (1994), examined the case using simultaneous equation system of insider ownership, leverage, and institutional ownership as independent variables. They found out that insitutional ownership acted as a substitute for managerial ownership and leverage in controlling agency conflict. Additionally, Chen and Steiner (1999) suggest that institutional ownership and managerial ownership had a substitutional effect on agency conflict control. Based on the empirical research, this study will use institutional ownership and leverage as control mechanism over agency conflict that happens as a result of asset utilization.

This study specifically examines the asset utilization managed by corporates. Several studies suggest a decline in company value during the announcement of tunneling-indicated related party transactions (Cheung, Rau, and Stouraitis, 2006 and Cheung, Qi, and Rau, 2009). Jian and Wong (2010) discovered that corporates performed tunneling by making receivables transaction with related parties to transfer the companies' outgoing resources. Furthermore, Cheung, Jing, Lu, and Rau (2009) found an empirical evidence that sales transactions and asset purchases from related parties were used to perform tunneling. On the other hand, Aharony et al., (2005) discovered that receivables transaction against related parties indicated tunneling after IPO (Initial Public Offering). Therefore, the objectives of this study are to examine: (1) institutional ownership as control mechanism over asset utilization, (2) leverage as control mechanism over asset utilization, (3) interdependence relationship between institutional ownership and leverage in performing control mechanism towards asset utilization, (4) the influence of asset utilization on corporate performance, (5) institutional ownership as control mechanism over corporate performance, and (6) leverage as control mechanism over corporate performance.

\section{Institutional Ownership and Asset Utilization}

The ability to exercise control can be different for different levels of ownership. Unlike lower institutional ownership level, higher level of institutional ownership means a more effective managerial control. Bukart, Gromb, and Panunzi (1997) reinforced this with a suggestion that 
ownership level provides incentives for owners to monitor managerial behaviours in a more effective way. On the other hand, Iskandar et al., (2012) suggest that concentrated ownership caneffectively increase the efficiency of asset utilization. A study conducted by Iturriaga and Crisostomo (2010) suggests a bell-shaped relationship between majority shareholders and corporate value. The active monitoring process conducted by the majority shareholders brings a positive result on corporate value. However, due to the increase in ownership level, majority shareholders tend to perform expropriation on minority shareholders. This action then affects corporate value negatively. Based on this empirical evidence, there is a tradeoff between monitoring effect through institutional ownership and asset utilization. It can also be said that the effect of expropriation through tunneling over asset utilization is a result of the behavioral change of institutional shareholders on different ownership levels. Based on that explanation, the research hypothesis can be formulated as follows:

H1: The influence of institutional ownership on asset utilization is positive when institutional ownership level is low and negative when institutional ownership level is high.

\section{Leverage and Asset Utilization}

Leverage works as an alternative way of transferring monitoring expenses from owners to lenders. Leverage should also encourage managers to be more disciplined in order to avoid bankruptcy. A research conducted by Maloney, McCormick and Mitchell (1993) suggests that leverage increases the decision making ability of the management. Additionally, Friend and Lang (1988) discovered that leverage could be used to reduce agency conflict by using external parties to oversee the management. Ade (2008) found a positive relationship between the external monitoring process conducted by banks as lenders towards total asset turnover. Based on that empirical evidence, it can be concluded that when leverage is low, the effect of control mechanism on asset utilization is low, whereas when leverage is high, the effect of control mechanism on asset utilization becomes stronger. The reason for this is because leverage is used to control the behaviour of institutional shareholders who perform expropriation through tunneling towards asset utilization. Th said action can bring loss to banks or lenders which lend money to the company. Based on this explanation, the hypothesis of this research can be formulated as follows:

$\mathrm{H}$ 2: The influence of leverage on asset utilization is negative when leverage level is low and positive when leverage level is high.

\section{Institutional Ownership and Leverage}

Jensen, Solberg and Zorn (1992) discovered that leverage and dividends were complementarily used to reduce agency costs but failed to prove that insider ownership was a substitution for leverage and dividends in controlling agency costs. Bathala, Moon and Rao (1994) also examined the simultaneous equation model based on insider ownership, leverage, and institutional ownership variables. They concluded that institutional ownership acted as a substitute for managerial ownership and leverage. On the other hand, Chen and Steiner (1999) found substitutional relationships between leverage, managerial ownership, dividends, and risks as well as between institutional ownership and managerial ownership. Finally, Crutchley et al., (1999) found a substitutional relationship between ownership structure and leverage or dividends. This empirical evidence suggests that institutional ownership and leverage can be effectively used as control mechanism on agency conflict. When the control mechanism performed through institutional ownership or leverage is weak, then the control mechanism performed by the company can be categorized as having a complementary relationship (positive relationship). On the other hand, when the institutional ownership or leverage is strong, then the control mechanism performed by the company has a substitutional relationship 
(negative relationship). Based on the above explanation, the hypothesis for this research can be formulated as follows:

H3: Linear institutional ownership and leverage show a positive (complementary) relationship, whereas non-linear insitutional ownership and leverage show a negative relationship (substitutional).

\section{Asset Utilization and Corporate Performance}

The effect of asset utilization on corporate performance is influenced by tunneling-indicated related party transactions. Tunneling may occur through cash flow tunneling and asset tunneling (Atasanov et al., 2007). Jian and Wong (2010) found that corporates used receivables transactions with related parties via tunneling to transfer the corporates' outgoing resources. Aharony et al., (2005) also suggest that loan transactions to related parties are used as means of tunneling after IPO. On the other hand, Cheung, Jing, Lu, and Rau (2009) discovered an empiracal evidence which suggested that public companies in Hongkong performed asset tunneling through related party transactions. This happened because public companies were trading with related parties at higher price than independent parties. Therefore, asset sales to related parties under reasonable price (tunneling out) would indirectly affect the financial performance through the loss of potential synergy between assets affected by tunneling and the remaining assets (Atasanov et al., 2007). Meanwhile, asset purchases from related parties at higher value than reasonable price (tunneling in) would result in a decrease in corporate profitability (Atasanov et al., 2007). Therefore, the increase in asset utilization will go in line with the increase in corporate performance as a result of the implementation of control mechanism through institutional ownership and leverage. Some research studies, including Wang, (2010) and Pouraghajan et al., (2013) suggest that asset utilization has a positive effect on corporate performance. Based on the explanation, the hypothesis for this research can be formulated as follows:

H4: Asset utilization has a positive influence on corporate performance.

\section{Institutional Ownership and Corporate Performance}

Duggal and Millar (1999) suggest that institutional ownership play several important roles in improving the efficiency of capital markets. Firstly, institutional investors are considered as having better and more sophisticated research abilities in performing investment analysis. Secondly, high institutional ownership acts as an incentive for managerial supervision. Crutchley et al., (1999) reveal that institutional owners possess a more superior ability in management control than individual owners. Furthermore, Thomsen (2004) suggests that a concentrated ownership structure from majority shareholders has a non-linear correlation with corporate value. This means that when concentrated ownership structure is low, corporate value decreases. On the other hand, when the concentrated ownership structure is high, shareholders will hold internalization to protect their investments in the company. Kapopoulos and Lazaretou (2007) and Perrini et al, (2008) found that more concentrated ownership structure has a positive effect on the profitability of the company. Hu and Izumida (2008) also found a non-linear U-shaped effect between ownership concentration and corporate performance. This suggests a trade-off between expropriation effects and monitoring effects as a result of the behavioral changes within the majority shareholders at different levels of ownership concentration. It shows that higher ownership concentration leads to smaller acts of expropriation by majority shareholders, because they have to bear the increasing negative impacts of the expropriation. Cui and Mak (2002); Meca and Ballesta (2009); and Wellalage and Locke (2011) also found a nonlinear relationship between institutional ownership and corporate performance. They suggest that low 
institutional ownership leads to negative effects and high institutional ownership brings positive effects. Based on the above explanation, the hypothesis for this research can be formulated as follows:

H5: The influence of institutional ownership on corporate performance is negative when institutional ownership is low and positive when institutional ownership is high.

\section{Leverage and Corporate Performance}

Jensen (1986) found that the use of leverage encourages managers to be more disciplined in response to the increase in corporate financial risk. On the other hand, the use of leverage also prevents managers from taking excessive actions (over-investment) regarding internal capital which can lead to agency costs (residual loss) increase that the owners must bear (Hermeindito, 2012). Jensen (1986) argued that leverage helped prevent over-investment of free cash flow that managers do for their own benefits. Furthermore, Iturriaga and Crisostomo (2010) believed that leverage book value has a positive correlation with company value when investment opportunity is low. This shows that leverage can minimize the problem of over-investment. On the other hand, Beiner et al., (2006) found a positive relationship between leverage and corporate value and suggested using leverage as corporate governance mechanism in disciplining managers. In addition, some researchers have found a non-linear relationship between leverage and corporate performance. Kim and Sorensen (1996) and Hermeindito (2009) argued that the influence of leverage on corporate performance had a non-linear effect which showed positive signs in the beginning but indicated a negative effect when the leverage rose. This shows that higher leverage can lead to financial distress or even bankruptcy. Based on the explanation, the hypothesis for this research can be formulated as follows:

H6: The effect of leverage on corporate performance is positive when leverage level is low and negative when leverage level is high.

Based on the literature review and reseach hypothesis, a conceptual framework which consists of institutional ownership and leverage as part of control mechanism can be made. The framework will also include asset utilization and corporate performance as part of agency conflict. Below is the conceptual framework of this research:

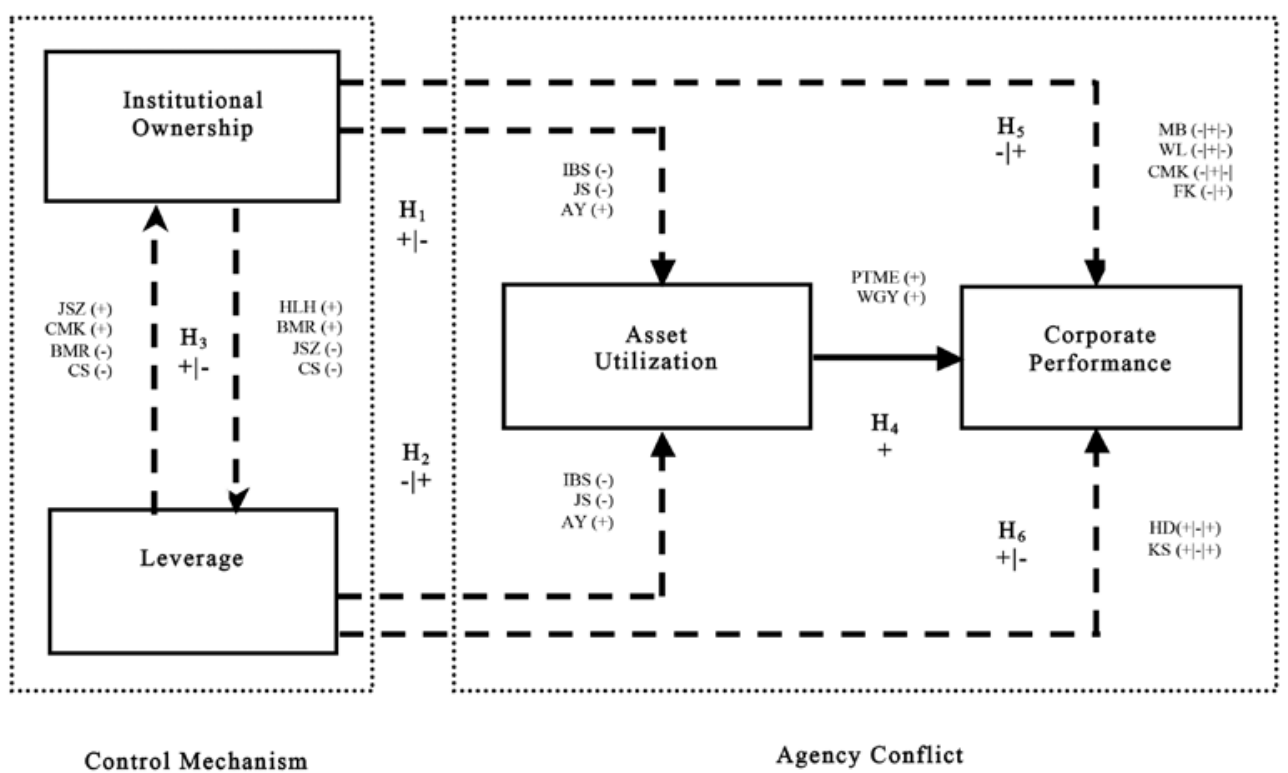

Picture 1. Research Conceptual Framework 
Notes:

----- The correlation between non-linear variables

The correlation between linear variables

- I + Non-linear variables in squared relationship indicate negative relationship at lower levels and positive relationship at higher levels

+1 - Non-linear variables in squared relationship indicate positive relationship at lower levels and negative relationship at higher levels

$+\quad$ Correlation between linear variables show a positive relationship Correlation between linear variables show a negative relationship

$-|+|-$ Non-linear variables in cubic relationship indicate negative relationship at lower levels,

positive relationship at higher levels, and negative relationship at even higher levels

$+|-|+$ Non-linear variables in cubic relationship indicate positive relationship at lower levels, negative relationship at higher levels, and positive relationship at even higher levels

$\begin{array}{ll}\text { FL } & \text { : Friend and Lang (1988) } \\ \text { JSZ } & \text { : Jensen, Solberg, and Zorn (1992) } \\ \text { BMR } & \text { : Bathala, Moon, and Rao (1994) } \\ \text { KS } & \text { : Kim and Sorensen (1996) } \\ \text { CS } & \text { : Chen and Steiner (1999) } \\ \text { CMK } & \text { : Cui and Mak (2002) } \\ \text { AY } & \text { : Ade (2007) } \\ \text { HD } & \text { : Hermeindito (2009) } \\ \text { JS } & \text { : Jelinek and Stuerke (2009) } \\ \text { MB } & \text { : Meca and Ballesta (2009) } \\ \text { WGY } & \text { : Wang (2010) } \\ \text { WL } & \text { : Wellalage and Locke (2011) } \\ \text { HLH } & \text { : Huang, Lin, and Huang (2011) } \\ \text { KS } & \text { : Kouki and Said (2011) } \\ \text { IBS } & \text { : Iskandar, Bukit, and Sanusi (2012) } \\ \text { FK } & \text { : Firdaus and Kusumastuti (20013) } \\ \text { PTME } & \text { : Pouraghajan et al., (2013) }\end{array}$

\section{METHODS}

The research data come in the form of panel data obtained from Indonesian companies between 2001 and 2012. The company sample selection criteria include: (1) companies audited between 2001 and 2012, amounting to 177 companies, (2) companies which provided complete information on financial statement data for all research periods with the exception of 17 companies which failed to do so, (3) companies that were not undergoing any acquisition, merger, or delisting process, because the financial data needed for the research cannot be obtained from companies which undergo the delisting process (a total of 3 companies fall under this category), and (4) companies which provided complete information on stock market data with the exception of 21 companies which failed to provide the required information. The final sample amount is 136 companies. Financial data were obtained from the Indonesian Capital Market Directory (ICMD) from 2001 to 2012. A second examination was then conducted by comparing the data from ICMD and the annual financial statement from each company. Data were also obtained from Indonesian Securities Market Database (ISMD) published by the Faculty of Economics of Gadjah Mada University in Indonesia. Meanwhile, stock market data were obtained from the reports of Indonesia Stock Exchange (IDX). Table 1 describes the industry classification for the corporates based on the eight industry types used as samples in this research

The main variables in this research include Institutional Ownership (INST_OWN) which is the percentage of total institutional ownership (Crutchley et al., 1999; Herdinata and Efrata 2013); Leverage (LEVERAGE) which is the ratio between total leverage and total asset (Abor, 2007); Asset Utilization (ASSET_UT) which includes total sales and total asset (Wang, 2010); Corporate Performance (Q) which is a result of market value of equity added by total leverage and divided by total asset (Sulong and Nor, 2010; Imam and Malik, 2008; Bozec and Laurin, 2008; Thomsen, 
Table 1. Corporate Samples Based on Industry Types

\begin{tabular}{clc}
\hline No & \multicolumn{1}{c}{ Industry Type } & Number of Corporates \\
\hline 1 & Agriculture & 5 \\
\hline 2 & Mining & 4 \\
\hline 3 & Basic Industry and Chemicals & 25 \\
\hline 4 & Miscellaneous Industry & 19 \\
\hline 5 & Consumer Goods Industry & 20 \\
\hline 6 & Property, Real Estate, and Building Construction & 19 \\
\hline 7 & Infrastructure, Utilities, \& Transportation & 9 \\
\hline 8 & Trade, Services, \& Investment & 35 \\
\hline & Total & 136 \\
\hline
\end{tabular}

Source: Processed data

2004). Other controlling variables include Squared Institutional Ownership (INST_OWN²) which is the percentage of the squared total of institutional ownership (Crutchley et al., 1999); Squared Leverage (LEVERAGE ${ }^{2}$ ) which is the ratio between squared total leverage and squared total asset (Abor, 2007); managerial ownership (MGR_OWN_ DUM) which serves as a dummy variable which gives 1 for companies with managerial ownership and 0 for the rest (Hermeindito, 2012); Asset Structure (SA) which is the ratio between total fixed assets and total assets (Cliff and Herdinata, 2013); Return on Invested Capital (ROIC) which comes from NOPAT minus paid dividends and divided by the amount of long-term leverages and total equity which has been substracted by retained earnings balance (Stephen and David, 2009); Market to Book Value of Asset (MBVA) which is the ratio between market price equity and total assets (Adam and Goyal, 2008; Yuliani, Isnurhadi, and Bakar, 2013); Return on Asset (ROA) which is the ratio between net income and total assets (Hermeindito, 2012); Return on Asset Risk (RISK_ROA) which is a deviation standard of net income divided by total assets (Hermeindito, 2009; Herdinata and Cliff, 2013); Domestic Ownership (DOM_OWN) which is the percentage of domestic institutional ownership (Ismiyanti, 2007); Foreign Ownership (FORG_DUM) which serves as a dummy variable which gives 1 for companies with foreign ownership and 0 for the rest (Faisal,
2013); Operating Cash Flow (OCF) which is the ratio between operating cash flow and total assets (Hermeindito, 2009); Financial Distress (FDISS) which serves as a dummy variable which gives 1 for companies which do not experience financial distress and 0 for the rest (Hermeindito, 2012); Blockholder (BLOCK_DUM) which serves as a dummy variable which gives 1 for companies with ownership level above $5 \%$ and 0 for the rest (Chen and Steiner, 1999).

This study uses a simultaneous equation model with Three-Stage Least Square technique to test the research hypothesis. Simultaneous equation model is used in this research because the institutional ownership (INST_OWN) and leverage (LEVERAGE) variables in the analysis model are considered as endogenous and independent variables (Greene, 2008:690). The following equation models are the four models that have been developed and tested using the research hypothesis:

$\mathrm{Q}=\alpha_{1}+\beta_{11} \mathrm{ASSET}$ _UT $+\beta_{12}$ INST_OWN + $\gamma_{11}$ INST_OWN $^{2}+\beta_{13}$ LEVERAGE $+\gamma_{12}$ LEVERAGE $^{2}+$ $\delta_{11}$ MGR_OWN_DUM $+\delta_{12} \mathrm{SA}+\delta_{13} \mathrm{ROIC}+\delta_{14} \mathrm{ROA}$ $+\varepsilon_{1}$

ASSET_UT $=\alpha_{2}+\beta_{21}$ INST_OWN $+\gamma_{21}$ INST_OWN ${ }^{2}$ $+\beta_{22}$ LEVERAGE $+\gamma_{22}$ LEVERAGE $^{2}+\delta_{21}$ RISK_ROA $+\delta_{22} \mathrm{SA}+\delta_{23} \mathrm{ROIC}+\varepsilon_{2}$ 
INST_OWN $=\alpha_{3}+\beta_{31}$ LEVERAGE $+\gamma_{31}$ LEVERAGE $^{2}$ $+\delta_{31}$ DOM_OWN $+\delta_{32}$ FORG_DUM $+\delta_{33} \mathrm{OCF}+$ $\delta_{34}$ MGR_OWN_DUM $+\delta_{35}$ FDISS $+\varepsilon_{3}$

LEVERAGE $=\alpha_{4}+\beta_{41}$ INST_OWN $+\gamma_{41}$ INST_OWN $^{2}$ $+\delta_{41} \mathrm{SA}+\delta_{42}$ BLOCK_DUM

$+\delta_{43} \mathrm{MBVA}+\varepsilon_{4}$

The first identification process stage of the simultaneous equation model is applying order terms and rank conditions of identification to identify (Gujarati and Porter, 2012:382). This can be seen in the Coefficient Variable table in Table 2. The next stage is to calculate the issued pre-determined variables and the endogenous variables entered with $\mathrm{K}$ value as the number of pre-determined variables in the model, $\mathrm{k}$ value as the number of predetermined variables in every equation in the model, and $m$ value as the number of endogenous variables in every equation in the model. Based on the identification result of the simultaneous equation model as shown in Table 3 it can be seen that all equations are identified as Overidentified. The third stage involves hausmant test by means of reduced form. This can be done by adding all exogenous variables from other equations into the endogenous equation to get residual value. Reduced form will then be applied to the equations in the model. The fourth stage is based on the residual value obtained from the reduced form equation. The residual value will then be inserted back into the endogenous equation and analyzed using Ordinary Least Square (OLS). After OLS result is obtained, there needs to be a significant level checking of exogenous variables in the endogenous equation used which will then lead to significant value. Finally, a correlation test between residuals is performed. The fifth stage involves a correlation test between residuals with the help of Two-Stage Least Square (2SLS) method in the simultaneous equation. If there is a significant correlation between the residuals, the estimation technique used for the simultaneous equation model testing is Three-Stage Least Square (3SLS). This research shows that there is a significant correlation between the residuals as shown in the Residual Correlation Test result in Table 4 (Appendix). Therefore, the proper estimation technique is Three-Stage Least Square (3SLS).

Table 2. Variable Coefficient

\begin{tabular}{|c|c|c|c|c|c|c|c|}
\hline Equation No. & 1 & $\mathbf{q}$ & asset_ut & inst_own & leverage & inst_own ${ }^{2}$ & leverage $^{2}$ \\
\hline [1] & $-\alpha_{1}$ & 1 & $-\beta_{11}$ & $-\beta_{12}$ & $-\beta_{13}$ & $-\gamma_{11}$ & $-\gamma_{12}$ \\
\hline$[2]$ & $-\alpha_{2}$ & 0 & 1 & $-\beta_{21}$ & $-\beta_{22}$ & $-\gamma_{21}$ & $-\gamma_{22}$ \\
\hline [3] & $-\alpha_{3}$ & 0 & 0 & 1 & $-\beta_{31}$ & 0 & $-\gamma_{31}$ \\
\hline [4] & $-\alpha_{4}$ & 0 & 0 & $-\beta_{41}$ & 1 & $-\gamma_{41}$ & 0 \\
\hline Equation No. & & Igr_own_dum & sa & roic & roa & risk_roa & dom_own \\
\hline [1] & & $-\delta_{11}$ & $-\delta_{12}$ & $-\delta_{13}$ & $-\delta_{14}$ & 0 & 0 \\
\hline$[2]$ & & 0 & $-\delta_{22}$ & $-\delta_{23}$ & 0 & $-\delta_{21}$ & 0 \\
\hline [3] & & $-\delta_{34}$ & 0 & 0 & 0 & 0 & $-\delta_{31}$ \\
\hline [4] & & 0 & $-\delta_{41}$ & 0 & 0 & 0 & 0 \\
\hline Equation No. & & forg_dum & ocf & fdiss & \multicolumn{2}{|r|}{ block_dum } & mbva \\
\hline [1] & & 0 & 0 & 0 & \multicolumn{2}{|r|}{0} & 0 \\
\hline [2] & & 0 & 0 & 0 & \multicolumn{2}{|r|}{0} & 0 \\
\hline [3] & & $-\delta_{32}$ & $-\delta_{33}$ & $-\delta_{35}$ & \multicolumn{2}{|r|}{0} & 0 \\
\hline [4] & & 0 & 0 & 0 & \multicolumn{2}{|r|}{$-\delta_{42}$} & $-\delta_{43}$ \\
\hline
\end{tabular}


Table 3. Simultaneous Equation Model Identification

\begin{tabular}{cccc}
\hline Equation No. & $\begin{array}{c}\text { Predetermined Variables } \\
\text { Incurred, (K-k) }\end{array}$ & $\begin{array}{c}\text { Endogenous Variables } \\
\text { Entered, }(\mathrm{m}-1)\end{array}$ & Identification \\
\hline$[1]$ & 6 & 3 & Over Identified \\
\hline$[2]$ & 5 & 2 & Over Identified \\
\hline$[3]$ & 6 & 1 & Over Identified \\
\hline$[4]$ & 4 & 1 & Over Identified \\
\hline
\end{tabular}

Table 4. Cross-Residual Correlation Test

\begin{tabular}{clrrrr}
\hline & & Q & ASSET_UT & INST_OWN & LEVERAGE \\
\hline \multirow{2}{*}{ Q } & Pearson Correlation & 1 & $-0.267^{* *}$ & 0.011 & $-0.084^{* *}$ \\
& Sig. (2-tailed) & & 0.000 & 0.647 & 0.001 \\
& N & 1632 & 1632 & 1632 & 1632 \\
& Pearson Correlation & $-0.267^{* *}$ & 1 & $0.113^{* *}$ & $0.105^{* *}$ \\
ASSET_UT & Sig. (2-tailed) & 0.000 & & 0.000 & 0.000 \\
& N & 1632 & 1632 & 1632 & 1632 \\
& Pearson Correlation & 0.011 & $0.113^{* * *}$ & 1 & $0.490^{* * *}$ \\
INST_OWN & Sig. (2-tailed) & 0.647 & 0.000 & & 0.000 \\
& N & 1632 & 1632 & 1632 & 1632 \\
& Pearson Correlation & $-0.084^{* * *}$ & $0.105^{* *}$ & $0.490^{* * *}$ & 1 \\
LEVERAGE & Sig. (2-tailed) & 0.001 & 0.000 & 0.000 & \\
& N & 1632 & 1632 & 1632 & 1632 \\
\hline
\end{tabular}

Notes:

** = significance level at $1 \%$ (2-tailed)

\section{RESULTS AND DISCUSSION}

Table 5 presents a statistical description of the research variables in 1.632 observations based on the panel data. The average value of the Corporate Performance (Q) variable is 1.4273 . This means that the overall value of the market capitalization added by leverage book value is 1.4273 times more than asset value. The average value of Asset Utilization (ASSET_UT) variable is 0.9694. This means that, in general, corporates are able to utilize their assets to produce a sales rate of $96.94 \%$. The average value of Institutional Ownership (INST_OWN) variable is 0.6372 . This means that, in general, the total institutional ownership concentration is $63.72 \%$. The average value of Leverage (LEVERAGE) is 0.5968 , which means that the leverage ratio in general is $59.68 \%$. In other words, $59.68 \%$ of the company's total leverage is funded by the company's total assets.

Table 5 presents a summary of the statistic description of the research variables in the sample companies. The measurement of these variables is as follows: $\mathrm{Q}$ (corporate performance) $=$ (market value equity + total debt)/ total assets; INST_OWN (institutional ownership) $=$ percentage of total institutional ownership; INST_OWN2 = squared percentage of total institutional ownership; LEVERAGE (leverage) = total leverage / total asset; LEVERAGE2 = squared total debt / total assets; ASSET_UT (asset utilization) = total sales / total assets; MBVA = equity market price / asset 
Table 5. Descriptive Statistics of Variables

\begin{tabular}{cccccc}
\hline Variable & N & Mean & Std. Dev. & Maximum & Minimum \\
\hline Q & 1632 & 1.4273 & 1.6778 & 40.8053 & 0.0877 \\
\hline ASSET_UT & 1632 & 0.9694 & 0.7157 & 5.5355 & 0.0012 \\
\hline INST_OWN & 1632 & 0.6372 & 0.2359 & 0.9974 & 0.0000 \\
\hline INST_OWN $^{2}$ & 1632 & 0.4617 & 0.2610 & 0.9948 & 0.0000 \\
\hline LEVERAGE $^{2}$ & 1632 & 0.5968 & 0.4636 & 8.2499 & 0.0049 \\
\hline LEVERAGE & 1632 & 0.5710 & 2.0971 & 68.0621 & 0.0000 \\
\hline SA & 1632 & 0.6365 & 0.6358 & 13.2530 & 0.0019 \\
\hline ROIC & 1632 & 0.1249 & 0.8543 & 5.1469 & -20.4931 \\
\hline ROA & 1632 & 0.0627 & 0.2752 & 2.1845 & -9.1572 \\
\hline RISK_ROA & 1632 & 0.0415 & 0.2384 & 6.4461 & 0.0001 \\
\hline OCF & 1632 & 0.0642 & 0.1379 & 1.1360 & -1.6153 \\
\hline DOM_OWN & 1632 & 0.3745 & 0.3006 & 0.9963 & 0.0000 \\
\hline MBVA & 1632 & 0.8305 & 1.6130 & 36.7995 & 0.0038 \\
\hline FDISS & 1632 & 0.9313 & 0.2528 & 1 & 0 \\
\hline MGR_OWN_DUM & 1632 & 0.2297 & 0.4208 & 1 & 0 \\
\hline FORG_DUM & 1632 & 0.5202 & 0.4997 & 1 & 0 \\
\hline BLOCK_DUM & 1632 & 0.0992 & 0.2991 & 1 & 0 \\
\hline & & & & 1 \\
\hline
\end{tabular}

book value; RISK_ROA = deviation standard of net income / total assets; DOM_OWN = percentage of domestic institutional ownership; OCF = operating cash flow / total assets; ROA = net income / total assets; $\mathrm{SA}=$ total fixed assets $/$ total assets; $\mathrm{ROIC}=$ (NOPAT-paid dividends) / (long-term debt + total equity - retained earnings balance); FORG_DUM = dummy variable with the value of 1 for companies with foreign ownership and 0 for the rest; BLOCK DUM = dummy variable with the value of 1 for companies with an ownership rate higher than or equal to $5 \%$ and 0 for the rest; FDISS = dummy variable with the value of 1 for companies which do not experience financial distress and 0 for the rest; MGR_OWN_DUM = dummy variable with the value of 1 for companies with managerial ownership and 0 for the rest.

Table 6 is the test result on simultaneous equation model using Three-Stage Least Square estimation technique to test six hypotheses (H1-H6). Table 6 contains the test result of simultaneous equation model.

Table 6 presents a summary of the statistic description of the research variables in the sample companies. The measurement of these variables is as follows: $\mathrm{Q}$ (corporate performance) $=$ (market value equity + total debt $) /$ total assets; INST_OWN (institutional ownership) = percentage of total institutional ownership; INST OWN2 = squared percentage of total institutional ownership; LEVERAGE (leverage) = total leverage / total asset; LEVERAGE2 = squared total debt/total assets; ASSET_UT (asset utilization) = total sales / total assets; MBVA = equity market price / asset book value; RISK_ROA = deviation standard of net income / total assets; DOM_OWN = percentage of domestic institutional ownership; OCF = operating cash flow / total assets; ROA = net income / total assets; $\mathrm{SA}=$ total fixed assets $/$ total assets; $\mathrm{ROIC}=$ (NOPAT-paid dividends) / (long-term debt + total 
Table 6. Test Results of Simultaneous Equation Model

\begin{tabular}{|c|c|c|c|c|}
\hline Variable & $1: Q$ & 2: ASSET_UT & 3: INST_OWN & 4: LEVERAGE \\
\hline \multirow[t]{2}{*}{ INTERCEPT } & 5.1115 & 0.4733 & -0.3953 & -0.0353 \\
\hline & $(3.11) * * *$ & (1.33) & $(-1.34)$ & $(-0.14)$ \\
\hline \multirow[t]{2}{*}{ ASSET_UT } & 1.5488 & & & \\
\hline & $(2.59) * * *$ & & & \\
\hline \multirow[t]{2}{*}{ INST_OWN } & -19.4296 & 2.1845 & & 1.7676 \\
\hline & $(-3) * * *$ & $(1.65)^{*}$ & & $(1.97) * *$ \\
\hline \multirow[t]{2}{*}{ INST_OWN² } & 17.4662 & -2.1195 & & -2.0375 \\
\hline & $(3.1) * * *$ & $(-1.84) *$ & & $(-2.62) * * *$ \\
\hline \multirow[t]{2}{*}{ LEVERAGE } & 2.1356 & -0.3989 & 0.8434 & \\
\hline & $(5.39) * * *$ & $(-4.61) * * *$ & $(2.7) * * *$ & \\
\hline \multirow[t]{2}{*}{ LEVERAGE $^{2}$} & -0.0948 & 0.0238 & -0.1417 & \\
\hline & $(-1.61)$ & $(1.76) *$ & $(-3.64) * * *$ & \\
\hline \multirow[t]{2}{*}{ SA } & 0.7593 & 0.0591 & & 0.3848 \\
\hline & $(7.03) * * *$ & $(2.27) * *$ & & $(25.88) * * *$ \\
\hline \multirow[t]{2}{*}{ ROIC } & -0.1259 & 0.0187 & & \\
\hline & $(-2.83) * * *$ & $(1.74) *$ & & \\
\hline \multirow[t]{2}{*}{ ROA } & 1.0944 & & & \\
\hline & $(8.12) * * *$ & & & \\
\hline \multirow[t]{2}{*}{ RISK_ROA } & & 0.0950 & & \\
\hline & & $(2.65) * * *$ & & \\
\hline \multirow[t]{2}{*}{ OCF } & & & 0.1363 & \\
\hline & & & $(1.85) *$ & \\
\hline \multirow[t]{2}{*}{ MBVA } & & & & 0.0037 \\
\hline & & & & $(0.79)$ \\
\hline \multirow[t]{2}{*}{ FDISS } & & & 0.8673 & \\
\hline & & & $(4.73) * * *$ & \\
\hline \multirow[t]{2}{*}{ DOM_OWN } & & & 0.0830 & \\
\hline & & & $(2.26) * *$ & \\
\hline \multirow[t]{2}{*}{ MGR_OWN_DUM } & 0.3998 & & 0.0529 & \\
\hline & $(2.94) * * *$ & & $(2.18) * *$ & \\
\hline \multirow[t]{2}{*}{ FORG_DUM } & & & 0.0766 & \\
\hline & & & $(3.93) * * *$ & \\
\hline \multirow[t]{2}{*}{ BLOCK_DUM } & & & & 0.0971 \\
\hline & & & & $(3.91) * * *$ \\
\hline R-squared & 0.3404 & 0.7959 & 0.3571 & 0.7216 \\
\hline Adj. R-squared & 0.2711 & 0.7748 & 0.2906 & 0.6932 \\
\hline
\end{tabular}


equity - retained earnings balance); FORG_DUM = dummy variable with the value of 1 for companies with foreign ownership and 0 for the rest; BLOCK DUM = dummy variable with the value of 1 for companies with an ownership rate higher than or equal to $5 \%$ and 0 for the rest; FDISS = dummy variable with the value of 1 for companies which do not experience financial distress and 0 for the rest; MGR_OWN_DUM = dummy variable with the value of 1 for companies with managerial ownership and 0 for the rest. $* * *=$ significance level at $1 \% ; * *=$ significance level at $5 \%$; $=$ significance level at $10 \%$.

\section{Institutional Ownership and Asset Utilization}

The test result of simultaneous equation model using the Three Stage Least Square estimation technique in Table 6 shows that the variable coefficient of institutional ownership is at a low level $\left(\beta_{21}=2.1845\right)$ with a positive sign and a significance level of $10 \%$, whereas at a higher level $\left(\gamma_{21}=-2.1195\right)$, it shows a negative sign with a significance level of $10 \%$. As a result, Hypothesis 1 is proven. When institutional stockholders perform a control mechanism over asset utilization, they also take an active monitoring function in the company. This action brings a positive influence towards asset utilization. However, when institutional ownership concentration is high, they obtain almost all controls within the company and increase the moral hazard to conduct expropriation through related party transactions. Majority shareholders use this condition to conduct tunneling which brings a disadvantage to minority shareholders and results in the decline of asset utilization. This non-linear effect is an evidence that there is a conflict between majority shareholders and minority shareholders. This research is supported by Iturriaga and Crisostomo (2010) who applied a squared regression model to test the correlation between ownership concentration and corporate value and discovered a bell-shaped relationship between the two variables. They also suggested that ownership concentration increased corporate value in the beginning, but when the concentration level reached certain threshold, the majority shareholders conducted an active monitoring role towards the company management which resulted in a positive impact on corporate value. Nonetheless, with the rise of concentrated ownership after certain threshold, majority shareholders will possess enough power to conduct expropriation towards minority shareholders and this will bring a negative impact to corporate value. Therefore, there is a tradeoff between control mechanism effects on asset utilization monitoring via institutional ownership and agency conflict effects on asset utilization tunneling at high level of concentrated insitutional ownership. This condition can be seen in Picture 2 below:

Asset

Utilization

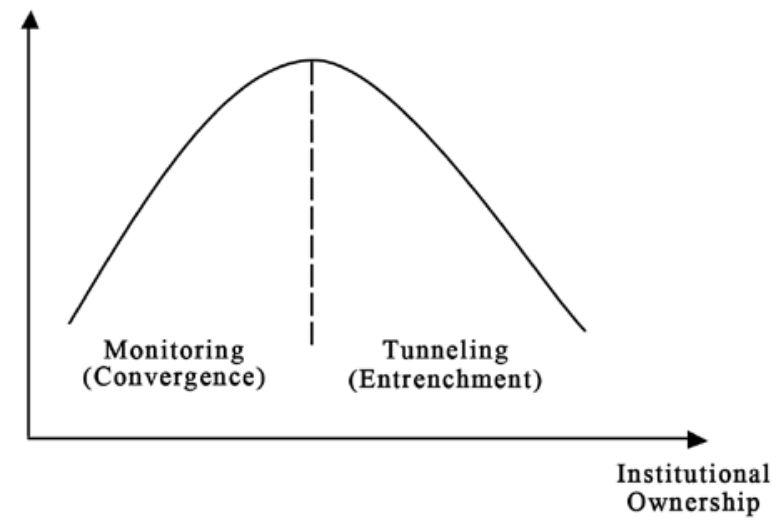

Picture 2. The Effect of Institutional Ownership on Asset Utilization at Higher Levels of Ownership Concentration

\section{Leverage and Asset Utilization}

The test result of simultaneous equation model using the Three Stage Least Square estimation technique in Table 6 shows that the variable coefficient of leverage is at a low level $\left(\beta_{22}=\right.$ -0.3989) with a negative sign and a significance level of $1 \%$, whereas at a higher level $\left(\gamma_{22}=\right.$ 0.0238), it shows a positive sign and a significance level of $10 \%$. Therefore, Hypothesis 2 is proven. When leverage is low, creditors or banks perform 
a relatively low monitoring function in the company. This brings a negative effect towards asset utilization because institutional shareholders can conduct expropriation through tunneling on creditors or banks which will lead to the decline in asset utilization. However, when leverage is high, creditors or banks obtain almost all control in asset utilization and this condition may result in the reduction in expropriation by means of tunneling. Friend and Lang (1988) discovered that leverage could be used to reduce agency conflict by inviting external parties to supervise the management. The applied leverage can also serve as a control system for the company by using banks or creditors to optimize asset utilization and improve corporate performance. Ade (2008) suggested a positive relationship between external monitoring by banks and total asset turnover. This shows that leverage can be used to control asset utilization. When leverage is high, banks or creditors will be more strict with their monitoring function. As a result, asset utilization will increase. Therefore, it can be concluded that there is a trade-off between control mechanism effects via asset utilization monitoring and agency conflict effects via asset utilization tunneling at high leverage level. This condition can be seen in Picture 3 .

\section{Institutional Ownership and Leverage}

The test result of simultaneous equation model using the Three Stage Least Square estimation technique in Table 6 shows that the variable coefficient of leverage on institutional ownership in linear terms $\left(\beta_{31}=0.8434\right)$ is positive with a significance level of $1 \%$. Meanwhile, in non-linear terms $\left(\gamma_{31}=-0.1417\right)$, it shows positive sign with a significance level of $1 \%$. Furthermore, the variable coefficient of institutional ownership towards leverage in linear terms $\left(\beta_{41}=1.7676\right)$ is positive with a significance level of $5 \%$, whereas the non-linear terms $\left(\gamma_{41}=-2.0375\right)$ shows a positive sign with a significance level of $1 \%$. As a result, Hypothesis 3 is proven. Institutional ownership and leverage in linear testing shows a complementary relationship. This suggests that institutional
Asset

Utilization

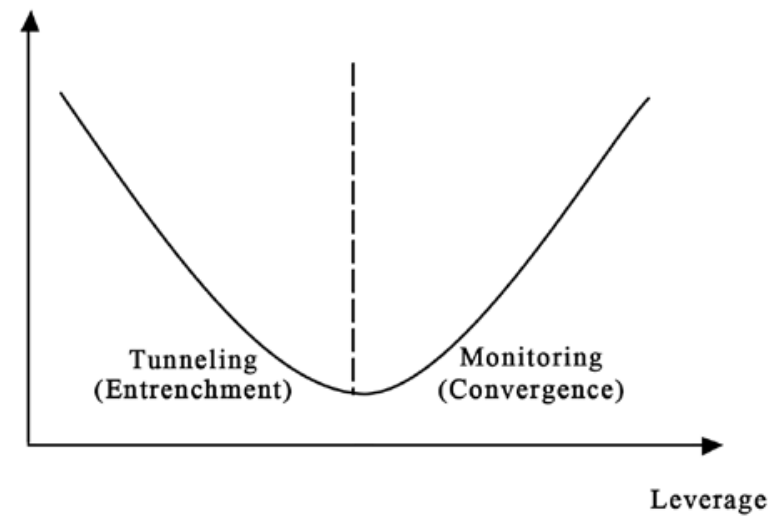

Picture 3. The Effect of Leverage on Asset Utilization at Higher Levels of Leverage

ownership and leverage have complementary fuctions in performing control mechanism towards asset utilization and corporate performance. On the other hand, insitutional ownership and leverage show substitutional functions in nonlinear testing. This suggests that only one of institutional ownership or leverage can be used to perform control mechanism towards asset utilization and corporate performance. These findings complement previous findings which suggest that there is a substitutional relationship between institutional ownership and leverage in doing a control mechanism on corporate value. Bathala, Moon, and Rao (1994) believe that institutional ownership can be used as a substitute for managerial ownership and leverage. Likewise, Chen and Steiner (1999) also suggest that leverage, managerial ownership, dividends, and risks have substitutional effects. In addition, they also found out that institutional ownership and managerial ownership had a substitutional relationship. Finally, Crutchley et al., (1999) also discovered a substitutional relationship between ownership structure and leverages or dividends.

\section{Asset Utilization and Corporate Performance}

The test result of simultaneous equation model using the Three Stage Least Square estimation technique in Table 6 shows that the variable 
coefficient of asset utilization $\left(\beta_{11}=1.5488\right)$ is positive with a significance level of $1 \%$. Hypothesis 4 suggests that asset utilization gives a positive impact on corporate performance. Therefore, this hypothesis is proven. When asset utilization is controlled properly through institutional ownership and leverage, there will be a positive impact on corporate performance. Therefore, institutional ownership and leverage should do an active monitoring role in the company to reduce expropriation through tunneling. This action will affect corporate performance positively. The relationship between asset utilization and corporate performance can be influenced by tunneling-indicated related party transactions. Tunneling can be conducted through cash flow tunneling and asset tunneling (Atasanov et al., 2007). Therefore, an effective and efficient implementation of control mechanism on asset utilization through institutional ownership and leverage can control asset utilization and bring a positive impact on corporate performance. Past studies which supported the stance which states that asset utilization brings a positive influence towards corporate performance include Wang, (2010); and Pouraghajan et al., (2013).

\section{Institutional Ownership and Corporate Performance}

The test result of simultaneous equation model using the Three Stage Least Square estimation technique in Table 6 shows that the variable coefficient of institutional ownership at lower level $\left(\beta_{11}=1.5488\right)$ is negative with a significance level of $1 \%$. It also shows a positive sign with a significance level of $1 \%$ at higher level $\left(\gamma_{11}=17.4662\right)$. Therefore, Hypothesis 5 is proven. Control mechanism via institutional ownership can reduce agency conflict and improve corporate performance. This monitoring process becomes relevant for business owners because it is associated with the wealth owned by the companies since the increase in institutional ownership will reduce possible agency conflicts. Therefore, higher level of institutional ownership means that the control mechanism performed by institutional shareholders is stronger due to low amount of agency conflict. Some researchers have identified a non-linear relationship between institutional ownership and corporate performance. Cui and Mak (2002); Thomsen (2004); and Hu and Izumida (2008) found a non-linear effect on the relationship between institutional ownership and corporate performance and suggest that when ownership is low, the effect is negative and when it is high, the effect is positive.

\section{Leverage and Corporate Performance}

The test result of simultaneous equation model using the Three Stage Least Square estimation technique in Table 6 shows that the variable coefficient of leverage at lower level $\left(\beta_{13}=2.1356\right)$ is positive with a significance level of $1 \%$, whereas at higher level $\left(\gamma_{12}=-0.0948\right)$, it shows negative sign and is considered to be insignificant. Therefore, Hypothesis 6 is not proven. Business owners apply leverage by involving banks or creditors to do a monitoring role in order to maximize corporate performance. The monitoring function becomes relevant because it is associated with the funds that the creditors or banks lend to the company in the hope that the company will be able to pay both the interest and the principal amount when the payment is due. Therefore, higher leverage means stronger control mechanism via leverage to improve corporate performance. On the other hand, when leverage is high, there will be a tradeoff between the monitoring cost incurred through leverage and the bankruptcy cost because of the increase in interest rate and loan principal carried by the company. As a result, institutional shareholders will try to maintain an optimal level of monitoring cost in conducting control mechanism through leverage. Several researchers have discovered a non-linear relationship between leverage and corporate performance. Kim and Sorensen (1996) and Hermeindito (2009) believed that leverage has a non-linear effect on corporate performance by showing a positive sign in the beginning and a negative trend at higher levels 


\section{MANAGERIAL IMPLICATIONS}

Managers need to evaluate and restructure the company's assets by considering an efficient business portfolio concept. This is evident with a proper control mechanism on asset utilization to improve corporate performance. Investors also need to perform an evaluation towards the behaviors of the managers in making policies related to the utilization of company assets. On the other hand, investors also need to consider the creditors' behaviour in monitoring the funding that the company receives, as well as observing the corporates' ability to pay due loan principals and interests. Additionally, decision makings made by business owners to change the ownership composition which involves institutional shareholders nees to be precise. This should be done so that the trade-off between expropriation effect and monitoring effect which comes as a result of the change in majority shareholders' behaviors will not bring a loss to investors despite tunneling. This study also gives an implication to creditors and banks in terms of lending decisions and control functions they set for the companies. Finally, this research also provides an implication for capital market regulation and suggests that it should improve the monitoring on information related to related-party transactions (tunneling) investors need to prevent loss.

\section{CONCLUSION}

Control mechanism via institutional ownership on asset utilization is more dominant at higher levels. Therefore, it brings positive and significant effects. However, an overly-high institutional ownership level may lead to expropriation through tunneling which results in a negative and significant impact on asset utilization. On the other hand, control mechanism via leverage is more dominant at higher levels and brings a positive and significant effect on asset utilization, whereas lower leverage level leads to expropriation and gives a negative and significant effect on asset utilization. In the context of non-linear relationship, the correlation between institutional ownership and leverage is negative and significant. This shows that institutional ownership and leverage have a substitutional relationship in non-linear context. In addition, the effect of asset utilization on corporate performance is positive and significant. This suggests that asset utilization can be properly controlled to improve corporate performance. The influence of institutional ownership on corporate performance at institutional shareholder ownership level is still low. This results in expropriation which affects corporate performance negatively and significantly. This happens because negative impact of the decline in corporate performance as a result of expropriation only slightly affects the related parties.

On the other hand, when institutional shareholder ownership level is high, there will be a positive and significant influence on corporate performance. This happens because the parties involved reduce the act of expropriation since they suffer the most in the negative impact of the decline in corporate performance. Corporate control mechanism through leverage on corporate performance is a way to control the efficiency of monitoring cost. However, this proves to be insignificant in this study. Some recommendations for future research include the threshold borderline issue which shows that institutional ownership and leverage can be used as control mechanism as well as the issue of companies inside and outside the affiliation group which can show the tunneling-indicated related party transactions. The limitation in this study is that the available ultimate shareholder data have not been well-documented in Indonesia.

Therefore, there is an insufficient amount of data to classify the ultimate shareholders into managerial ownership or independent groups. The difference in the classification may lead to different conclusions. The testing in this study is limited to non-linear context in the form of squared calculation. To study the influence pattern of control mechanism on institutional ownership and leverage towards asset utilization and corporate 
performance as part of agency conflict, a nonlinear study in the form of cubic shape can be used to determine a clearer pattern shape.

\section{REFEREN CES}

Abor, Joshua. (2007). Debt policy and performance of SMEs, Evidence from Ghanaian and South African firms. The Journal of Risk Finance, Vol 8 No. 4, 2007, pp 364-379.

Adam, T. and Goyal, V. K. (2008). The Investment Oppurtunity Set and Its Proxy Variables. The Journal of Financial Research, Vol. 11, pp. 41-63.

Ade, Yustina. (2007). Hubungan Struktur Kepemilikan dan External Monitoring Terhadap Agency Cost dan Aliran Kas. Jurnal Keuangan dan Perbankan, Vol.12, No.3 September, pp 343-354.

Aharony, J. Wang, J. and Yuan, H. (2005). Related Party Transaction: A Real Means of Earning Management and Tunneling during IPO Processin China. Working Paper. University of Tel Aviv.

Atasanov., Black., Ciccotello., and Gyoshev. (2007). How Does Law Affect Finance An Examination of Financial Tunneling in an Emerging Market. Law and Economics Workshop, pp.1-64.

Bathala, C.T., Moon, K.P., and Rao, R.P. (1994). Managerial Ownership, Debt Policy and The Impact of Institutional Holdings: An Agency Perspective. Journal of Financial Management, pp. 38-50.

Beiner, S., Drobetz, W., Schmid, M.M., and Zimmermann, H. (2006). Anintegrated framework of corporate governance and firm valuation. European Financial Management, 12, pp249-283.

Bozec, Y., and Laurin, C. (2008). Large share holder entrenchment and performance: Empirical evidence from Canada. Journal of Business Finance \& Accounting, 35, pp. 25-49.

Bukart, M., Gromb, D., and Panunzi, F. (1997). Large shareholders, monitoring, and the value of the firm. The Quaterly Journal of Economics, August, pp. 693-728.

Bozec, Y., dan Laurin, C. (2008). Large share holder entrenchment and performance: Empirical evidence from Canada. Journal of Business Finance \& Accounting, 35, pp. 25-49.

Cheung, Y., P. R Rau., and A. Stouraitis, (2006). Tunneling, propping and expropriation: Evidence from connected party transaction in Hongkong. Journal of Financial Economic, 82, pp. 343-386.

Cheung, Y. L., Qi, Y. H., and Rau, P. R. (2009). Buy high, sell low: how listed firms price asset transfers in related party transactions. Journal of Banking and Finance, 33(5), pp. 914-924.

Cheung, Y. L., Jing, L. H., Lu., T. and Rau, P. R. (2009). Tunneling and Propping up: an analysis of related party transactions by Chinese listed companies. Pacific-Basin Finance Journal, 17 (3), pp. 372-393.

Chen, C.R., and Steiner, T.L. (1999). Managerial Ownership and Agency Conflicts: A Nonlinear Simultaneous Equation Analysis of Managerial Ownership, Risk Taking, Deb Policy and Dividend Policy. The Financial Review 34, pp. 119-136.

Crutchley, C.E., Jensen, M.R.H., Jahera, J.S., and Raymond, J.E. (1999). Agency Problem and The Simultaneity of Financial Decision Making: The Role of Institutional Ownership. International Review of Financial Analysis 8/2, pp. 177-197.

Cui and Mak. (2002). The relationship between managerial ownership and firm performance in high R\&D firms. Journal of Corporate Finance 8, pp. 313-336.

Duggal, Rakesh., and James A. Millar. (1999). Institusional ownership and firm performance: The case of bidder return. Journal of Corporate Finance 5, pp. 103-117.

Faisal. (2013). Mekanisme Pengendalian Konflik Keagenan Antara Pemegang Saham Mayoritas dan Minoritas Studi Empiris Di Bursa Efek Indonesia. Dissertation. Post Graduate Program of Gadjah Mada University.

Firdaus, Nur and Kusumastuti, Retno. (2013). How Ownership Structure Influences Firm Performance in Relation to Its Life Cycle. International Research Journal of Business Studies, Vol. 5, No. 3, pp. 181-193.

Friend, I. and Lang, L.H.P. (1988). An Empirical Test of the Impact of Managerial Self-Interest on Corporate Capital Structure. Journal of Finance, 43, pp. 271-282.

Greene, William H. (2008). Econometric Analysis. Sixth Edition, Prentice Hall Inc. Upper Saddle River New Jersey.

Gujarati, Damodar N. and Dawn C. Porter. (2012). Dasar-Dasar Ekonometrika. $5^{\text {th }}$ edition, Jakarta: Salemba Empat.

Herdinata, Christian., dan Efrata, C. Christian. (2013). Kepemilikan Institusional dan Aliran Kas Bebas: Studi Empiris Dalam Perspektif Agency Theory. Proceeding. Faculty of Economics, Universitas Kristen Maranatha.

Herdinata, Christian., dan Efrata, C. Christian. (2013). Managerial Ownership dan Leverage: Studi Empiris Pada Perusahaan Di Indonesia. Proceeding. Faculty of Economics, Universitas Muhammadiyah Sidoarjo. 
Hermeindito. (2009). Saling Keterkaitan antara Struktur Kepemilikan, Kebijakan Utang, dan Dividen dengan Kinerja Perusahaan dalam Perspektif Keagenan. Research Grant PHK A3. Widya Mandala Catholic University Surabaya.

Hermeindito. (2012). Leverage Dan Nilai Perusahaan: Studi Empiris Pengujian Teori Pertukaran dan Teori Keagenan. Research Report. Widya Mandala Catholic University Surabaya.

Hu, Y., and Izumida, S. (2008). The relationship between ownership and performance: A review of theory and evidence. International Business Research, 1, pp. 72-81.

Huang, Lin, and Huang. (2011). The influences of ownership structure: Evidence from China. Journal of Developing Areas is the property of Tennessee State University, College of Business.

Imam, M.O., and Malik, M. (2007). Firm performance and corporate governance through ownership structure: Evidence from Bangladesh Stock Market. International Review of Business Research Papers, 3, pp. 88-110.

Iskandar Mohd Takiah., Bukit Br Rina., and Sanusi Mohd Zuraidah. (2012). The Moderating Effect of Ownership Structure on The Relationship Between Free Cash Flow and Asset Utilization. Asian Academy of Management. Journal of Accounting and Finance, Vol 8, No.1, pp. 69-89.

Ismiyanti, F. (2007). Biaya keagenan Pada Mikrostruktur Pasar: Pendekatan Rentang Harga. Dissertation. Post Graduate Program of Gadjah Mada University.

Iturriaga, F.J.L., and Crisostomo, V.L. (2010). Do leverage, dividend payout, and ownership concentration influence firms value creation? An analysis of Brazilian firms. Emerging Market Finance \& Trade, 46, pp. 80-94.

Jelinek and Stuerke. (2009). The nonlinear relation between agency costs and managerial equity ownership, Evidence of decreasing benefits of increasing ownership. International Journal of Managerial Finance, Vol. 5 No. 2, 2009. pp. 156-178.

Jensen, M.C., and W. H. Meckling. (1976). Theory of the Firm: Managerial Behavior, Agency Cost, and Ownership Structure. Journal of Financial Economic, 3, October, pp. 305-360.

Jensen, M.C. (1986). Agency cost of free cash flow, Corporate Finance and Takeovers. American Economic Review, 76, May, pp. 323-329.

Jensen, G.R., D.P. Solberg., and T.S. Zorn. (1992). Simultaneous Determination of Insider Ownership, Debt, and Dividend Policies. Journal of Financial and Quantitative Analysis, 27, pp. 247-263.

Jian, M., and Wong, T.J. (2010). Propping and Tunneling throught related party trasaction. Review of Accounting Studies.

Johnson, Simon; P. Boone; A. Breach; and E. Friedman. (2000). Corporate Governance in Asian Financial Crisis. Journal of Financial Economic, 58, pp. 141-186.

Kapopoulos, P., and Lazaretou S. (2007). Corporate Ownership Structure and Firm Performance: Evidence from Greek Firms. Corporate Governance: An International Review, 15 (2), pp. 144-158.

Kohardinata, Cliff., and Herdinata, Christian. (2013). Kepemilikan Manajerial dan Kepemilikan Institusional Terhadap Kebijakan Leverage Melalui Pendekatan Kesempatan Bertumbuh dan Risiko Perusahaan. Jurnal Keuangan dan Perbankan, Vol. 17, No. 3, pp. 353-361.

Kim, S.W., and Sorenson, E. H. (1986). Evidence on The Impact of The Agency cost of debt on Corporate Debt Policy. Journal of Financial and Quantitative Analysis 21, pp. 131-144.

Kouki and Said. (2011). Does management ownership explain the effect of leverage on firm value? An analysis of French listed firms. Journal of Business Studies Quarterly, Vol. 3, No. 1, pp. 169-186.

Maloney, M.T., McCormick, R.E., and Mitchell, M.L. (1993). Managerial Decision Making and Capital Structure. Journal of Business 66, pp. 189-217.

Meca, E.G and Ballesta, Juan P.S. (2009). Corporate Governance and Earnings Management: A Meta-Analysis. Corporate Governance: An International Review, Vol. 17, No. 5, pp. 594-610.

Perrini, F., Rossi, G., and Rovetta B (2008). Does Ownership Structure Affect Performance? Evidence from Italian Market. An International Review, Vol. 16, No. 4.

Pouraghajan, Tabari, Mansourinia, and Emamgholipour. (2013). Investigation the Effect of Financial Ratios, Operating Cash Flows and Firm Size on Earnings Per Share: Evidence from the Tehran Stock Exchange. International Research Journal of Applied and Basic Sciences.

Shleifer, A., and Vishny, R.W. (1986). Large Shareholders and Corporate Control, Journal of Political Economy, 94, pp. 461-488.

Stephen, and David. (2009). Why Capital Efficiency Measures Are Rarely Used In Incentive Plans, and How to Change That. Journal of Applied Corporate Finance, Vol. 21, pp. 87-92.

Sulong, Z., and Nor, F.M. (2010). Corporate governance mechanisms and firm valuation in Malaysian listed firms: A panel data analysis. Journal of Modern Accounting and Auditing, 6, pp. 1-19.

Thomsen, S. (2004). Blockholder ownership, dividends, and firm value in continental Europe. Department of International Economics and Management, Copenhagen Business School.

Wang, G. Yungchih. (2010). The Impacts of Free Cash Flows and Agency Costs on Firm Performance. Journal Service Science \& Management 3, pp. 408-418. 
Wellalege and Locke. (2011). Ownership structure and firm financial performance: Evidence from panel data in Sri Lanka. Journal of Business Systems, governance and Ethics. Vol. 7, No. 1.

Yuliani, Isnurhadi, and Bakar, Samardi W. (2013). Keputusan Investasi, Pendanaan, dan Dividen Terhadap Nilai Perusahaan Dengan Risiko Bisnis Sebagai Variabel Mediasi. Jurnal Keuangan dan Perbankan, Vol 17, No. 3, pp. 362-375 